Research Article

\title{
Decomposition of Cyanide from Gold Leaching Tailings by Using Sodium Metabisulphite and Hydrogen Peroxide
}

\author{
Dongzhuang Hou $\mathbb{D},{ }^{1}$ Lang Liu $\mathbb{D},{ }^{2}$ Qixing Yang, ${ }^{2}$ Bo Zhang, ${ }^{2}$ Huafu Qiu, ${ }^{2}$ Shishan Ruan, ${ }^{2,3}$ \\ Yue Chen, ${ }^{1}$ and Hefu $\mathrm{Li}^{4}$
}

${ }^{1}$ College of Geology and Environment, Xi'an University of Science and Technology, Xi'an 710054, China

${ }^{2}$ Energy School, Xi'an University of Science and Technology, Xi'an 710054, China

${ }^{3}$ Xi'an Fill Green-innovation Mining Technology Co. Ltd., Xi'an 710054, China

${ }^{4}$ Shanyang Qinding Mining Co. Ltd., Shangluo, 726400, Shanxi, China

Correspondence should be addressed to Lang Liu; liulang@xust.edu.cn

Received 16 July 2020; Revised 10 September 2020; Accepted 22 September 2020; Published 7 October 2020

Academic Editor: Erol Yilmaz

Copyright (C) 2020 Dongzhuang Hou et al. This is an open access article distributed under the Creative Commons Attribution License, which permits unrestricted use, distribution, and reproduction in any medium, provided the original work is properly cited.

\begin{abstract}
Cyanidation is widely used by most gold mine worldwide and will remain prevail in years (or decades) to come, while cyanide is hazardous, toxic pollutants whose presence in wastewater and tailings can seriously affect human and its environment; hence, it is necessary to control these contaminants. The purpose of this study was to examine the effects through the investigation of changes in $\mathrm{pH}$, concentration, and contact time, and the optimal conditions were obtained. It has been proven that the decomposition of cyanide in solution and tailings increased as the alkalinity in the presence of $0.5 \mathrm{~g} / \mathrm{L} \mathrm{Na}_{2} \mathrm{~S}_{2} \mathrm{O}_{5}$. An increase in $\mathrm{H}_{2} \mathrm{O}_{2}(30 \%$ ) concentration (from 1 to $4 \mathrm{~mL} / \mathrm{L}$ ) increased the decomposition in solution, while the effect on removing cyanide was better when $\mathrm{pH}$ was 9 than 8 and 10 in tailings. The cyanide in tailings decreased in the first $4 \mathrm{~h}$ and increased after $4 \mathrm{~h}$. The effective and economic conditions for maximum decomposition of cyanide from leach tailings are first treated in $0.5 \mathrm{~g} / \mathrm{L} \mathrm{Na}_{2} \mathrm{~S}_{2} \mathrm{O}_{5}$ at $\mathrm{pH} 10$ for 3 hours and then $2 \mathrm{~mL} / \mathrm{L} \mathrm{H}_{2} \mathrm{O}_{2}(30 \%)$ is added to the tailings at $\mathrm{pH} 9$ for 4 hours through comparative study. The findings provide the basis to optimize the decomposition of cyanide from gold leaching tailings in mining or backfilling by using the synergetic effect of $\mathrm{Na}_{2} \mathrm{~S}_{2} \mathrm{O}_{5}$ and $\mathrm{H}_{2} \mathrm{O}_{2}$.
\end{abstract}

\section{Introduction}

Cyanide leaching (cyanidation), which converts the gold into a cyanide complex $\left(\mathrm{Au}(\mathrm{CN})_{2}{ }^{-}\right)$that is soluble in water, is currently the most prevailing and effective process to extract gold from ores $[1,2]$. This process requires excess cyanide to improve gold recovery and produces exceptionally large quantities of cyanide-bearing wastes in the form of tailings and waters. Free cyanide, which is the main byproduct that results from metallurgical processes [3], is considered the most toxic cyanide form as it causes harmful effects at relatively low concentration. Other cyanide species are easily dissolved to free cyanide under acid conditions [4]. It will take a longtime for cyanide in the tailings to be reduced to biologically harmless through natural attenuation [5-7], so tailings containing cyanide should be treated before they are released into the environment to avoid detrimental effects on the receiving environment [8]. The decomposition of cyanide from gold leaching tailings is one of the biggest challenges for the gold mine in the last decades, so the appropriate treatment of the cyanide in the tailings is required to avoid or minimize environmental and health issues.

Several biological, physical, and chemical techniques, electrolytic oxidation, and other methods to decompose or recycle cyanide have been developed for the treatment of cyanide solutions. Currently, as the widely used technologies for industrial production of the decomposition of cyanide are INCO process, alkali-chlorine process, activated carbon process, ozone oxidation process, hydrogen peroxide oxidation process [9], and recovery hydrogen cyanide [10-12]. INCO and alkali-chlorine processes are used to remove high 
concentration cyanide, while they cannot completely accomplish the degradation of cyanide species [13, 14]. Activated carbon can absorb cyanide and make it gather, but cannot decompose it [15]. Ozonation and hydrogen peroxide oxidation processes, which are not easy to produce secondary pollution in the treatment of cyanide, are used to treat low concentration cyanide [16, 17], but the cost is higher. Recovery hydrogen cyanide can reduce cyanide content and cost, but it cannot meet the requirements of tailings' backfilling [10-12].

Backfilling technology is the best choice for the mine to break through the bottleneck of resources, environment, and safety [18], but harmful substances such as metal materials and solvent left in the gold leaching tailings should be treated before backfilling in order to prevent them from polluting groundwater. Many organizations and countries around the world have already issued effective cyanide management policies; some countries, include Costa Rica, Argentina, Germany, the Czech Republic, and Turkey, have an outright ban on the use of cyanide in gold extraction throughout the country $[19,20]$. In 2018, China issued the technical specification for pollution control of cyanide leaching residue in gold industry (TSPC), in which ozonation and hydrogen peroxide oxidation are selected as a method of deep decyanation. The study on cyanide removal is mainly focused on industrial wastewater [21]; the study on cyanide removal in gold leaching tailings, which contains wastewater and tailings, is still limited. While the mineral composition of gold ore is complex, cyanide, powder of activated carbon, hydrogen peroxide $\left(\mathrm{H}_{2} \mathrm{O}_{2}\right)$ and other chemical were also added in the mineral processing flowsheet, which made the composition of tailings more complex. Most of the residual cyanide in tailings are strongly adsorbed on the surface of minerals, only a small amount of free cyanides and hydrolytic complex cyanides are able to enter into the leaching solution [22].Therefore, it is necessary to explore more efficient methods to remove cyanide. The appropriate decomposition of $\mathrm{CN}^{-}$is a complex process that requires several approaches are combined to improve the efficiency of the treatment and consider treatment economy, and combination methods were used to try to remove cyanide [23].

Based on the method of cyanide removal in solution, the effects of $\mathrm{pH}$, concentration, and contact time of $\mathrm{H}_{2} \mathrm{O}_{2}$ for the decomposition of cyanide from leach tailings were analysed after $\mathrm{Na}_{2} \mathrm{~S}_{2} \mathrm{O}_{5}$ reaction. The mechanism of cyanide removal was also discussed. The outcome of this study was to find the best conditions for decomposition of cyanide from leach tailings, lead to bulk utilization of tailings in gold metal mine, and alleviate the ground collapse and soil pollution caused by traditional mining.

\section{Materials and Methods}

2.1. Tailings. The gold leaching tailings used in the experiment comes from Xiajiadian gold mine, Shaanxi province, China, which belongs to orogenic gold deposit, accounting for $52 \%$ in China [24]. The concentration of gold leaching tailings, where the diameter of tailings is $100-600 \mu \mathrm{m}$, is $35 \%, \mathrm{pH}$ is 10.78 , the initial cyanide concentration in the solution is $30.66 \mathrm{mg} / \mathrm{L}$, and the cyanide leached from the leach tailings is $11.78 \mathrm{mg} / \mathrm{L}$. The total carbon content of tailings is $2.47-6.67 \%$, in which the organic carbon content is $1.47-4.29 \%$. The solution temperature was controlled at $23 \pm 2^{\circ} \mathrm{C}$.

2.2. Reagents. $\mathrm{H}_{2} \mathrm{O}_{2}$ (30\%) and sodium metabisulphite $\left(\mathrm{Na}_{2} \mathrm{~S}_{2} \mathrm{O}_{5}\right)$ were employed as received. Copper employed as the decomposition catalysts $[25,26]$ was added as the copper sulfate for experiments. Concentrated (98\%) $\mathrm{H}_{2} \mathrm{SO}_{4}$ and $\mathrm{NaOH}$ were employed for $\mathrm{pH}$ adjustment. All chemicals were of analytical reagent grade. Agitated air was used in this experiment in order to accelerate the decomposition of cyanide, and the inflation rate was $50 \mathrm{~mL} / \mathrm{min}$.

\subsection{Methods}

2.3.1. Experiment of Decomposition of Cyanide from Leach Tailings. $0.5 \mathrm{~g} / \mathrm{L}$ of $\mathrm{Na}_{2} \mathrm{~S}_{2} \mathrm{O}_{5}$ and $0.2 \mathrm{~g} / \mathrm{L}$ of $\mathrm{CuSO}_{4}$ (as catalyst) were added to $1000 \mathrm{~mL}$ gold leaching tailings, and the solutions were air stirred at a constant rate of $50 \mathrm{~mL} / \mathrm{min}$ to accelerate cyanide oxidation. Individual experiments were carried out at $\mathrm{pH}$ values ranging from 8 to 11 . After $3 \mathrm{~h}$ at each $\mathrm{pH}, 10 \mathrm{~mL}$ sample solutions, which were filtered with a $0.45 \mu \mathrm{m}$ filter paper and a $100 \mathrm{~g}$ solid which was leaching residue, were analysed for residual cyanide. Then, 1, 2, or $4 \mathrm{~mL} / \mathrm{L}$ of $\mathrm{H}_{2} \mathrm{O}_{2}$ (30\%) was added to $1000 \mathrm{~mL}$ gold leaching tailings, which had been treated with $\mathrm{Na}_{2} \mathrm{~S}_{2} \mathrm{O}_{5}$ at $\mathrm{pH} 10$ for $3 \mathrm{~h}$. Individual experiments were carried out at $\mathrm{pH}$ values ranging from 8 to 10 , the solutions were air stirred at a constant rate of $50 \mathrm{~mL} / \mathrm{min}$ to accelerate cyanide oxidation. After $1 \mathrm{~h}, 2 \mathrm{~h}, 4 \mathrm{~h}$, and $8 \mathrm{~h}$ at each $\mathrm{pH}$, a $100 \mathrm{~g}$ solid which was leaching residue and some $10 \mathrm{~mL}$ sample cyanide wastewater were analysed for residual cyanide. $\mathrm{NaOH}$ or $\mathrm{H}_{2} \mathrm{SO}_{4}$ was added to maintain a $\mathrm{pH}$ of 8-11 throughout each test.

\subsubsection{Experiment of Cyanide Leaching from Leach Tailings.} The steps of cyanide leaching of leach tailings follow the technical specification for pollution control of cyanide leaching residue in gold industry issued by China. Contaminated cyanide solution was prepared by mixing the pregnant solution and water (extractant) according to the ratio of $10 \mathrm{~L}$ water to $1 \mathrm{~kg}$ tailings and oscillated at $30 \pm 2$ revolutions per min by flip oscillator with $23 \pm 2^{\circ} \mathrm{C}$ for $18 \pm 2$ hours referring to the technical specification for pollution control of cyanide leaching residue in gold industry.

2.3.3. Analytical Method. Total cyanide (CNT) content was determined by isonicotinic acid-pyrazolone spectrophotometry referring to the water quality-determination of cyanide volumetric and spectrophotometry method. The cyanide reacts with chloramine $\mathrm{T}$ to give cyanogen chloride, which reacts with isonicotinic acid to give pentenedialdehyde, and finally condenses with pyrazolone to give blue dye; then, it is measured at $638 \mathrm{~nm}$ by UV9100 A ultravioletvisible spectrophotometer (YQ00302), with a detection limit of $0.004 \mathrm{mg} / \mathrm{L}$. 


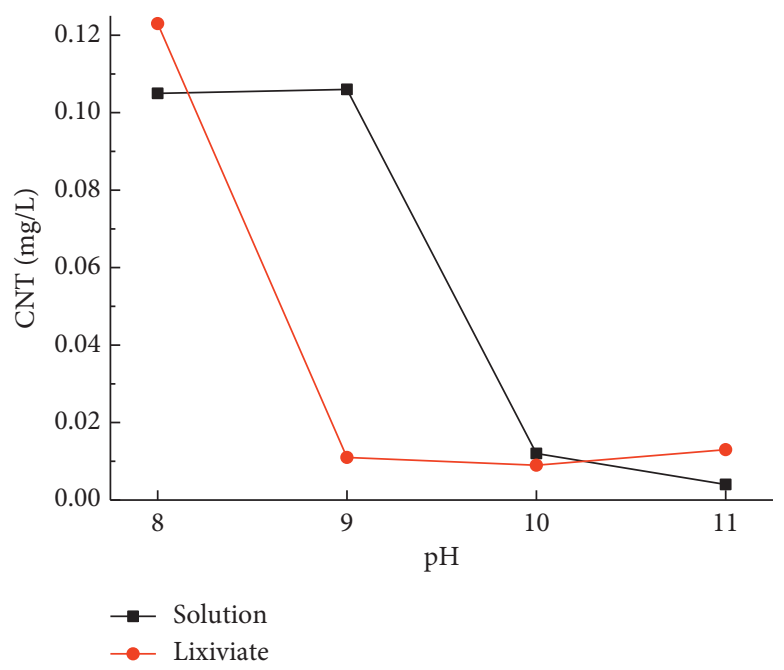

Figure 1: Cyanide as a function of $\mathrm{pH}$ in the presence of $0.5 \mathrm{~g} / \mathrm{l} \mathrm{Na} \mathrm{S}_{2} \mathrm{O}_{5}$ in 3 hours.

\section{Results and Discussion}

3.1. Effect of $\mathrm{pH}$ on the Decomposition of Cyanide by $\mathrm{Na}_{2} \mathrm{~S}_{2} \mathrm{O}_{5}$. Individual experiments were carried out at $\mathrm{pH}$ values ranging from 8 to 11 . Figure 1 shows the effect of equilibrium $\mathrm{pH}$ on the cyanide of solution and lixiviant in the presence of $0.5 \mathrm{~g} / \mathrm{L} \mathrm{Na}_{2} \mathrm{~S}_{2} \mathrm{O}_{5}$ in 3 hours. It is evident that an increase in $\mathrm{pH}$ increased the extent of decomposition of cyanide in solution and lixiviant of tailings. This result showed that the decomposition of cyanide increased as the alkalinity of the solution increased, the cyanide in lixiviant of tailings was the least when the $\mathrm{pH}$ was 10 under the same conditions, and the effect of cyanide decomposition in tailings was equivalent to that of $\mathrm{pH} 9,10$, and 11. Considering the investment cost, the effect of decomposition of cyanide from solution and tailing by $\mathrm{Na}_{2} \mathrm{~S}_{2} \mathrm{O}_{5}$ is the best when $\mathrm{pH}$ is 10 .

3.2. Effect of $p H$ on the Decomposition of Cyanide by $\mathrm{H}_{2} \mathrm{O}_{2}$. The $\mathrm{pH}$ value had a significant effect on cyanide removal $[21,27]$. The tailings were treated with $0.5 \mathrm{~g} / \mathrm{L} \mathrm{Na}_{2} \mathrm{~S}_{2} \mathrm{O}_{5}$ for 3 hours at $\mathrm{pH} \mathrm{10,} \mathrm{and} \mathrm{then} \mathrm{individual} \mathrm{experiments} \mathrm{were}$ carried out at $\mathrm{pH}$ values ranging from 8 to 11 . Figures $2(\mathrm{a})-$ 2(c) show the effect of equilibrium $\mathrm{pH}$ on the cyanide of lixiviant of tailings after $\mathrm{Na}_{2} \mathrm{~S}_{2} \mathrm{O}_{5}$ treatment in the presence of $\mathrm{H}_{2} \mathrm{O}_{2}$, and it is evident that the effect on removing cyanide was better when $\mathrm{pH}$ was 9 than 8 and 10 in lixiviant. Figure 2(d) shows effect of equilibrium $\mathrm{pH}$ on the cyanide of solution added with $2 \mathrm{~mL} / \mathrm{L} \mathrm{H}_{2} \mathrm{O}_{2}$ for 2 hour, and it is evident that an increase in $\mathrm{pH}$ increased the extent of decomposition in solution, which is in agreement with those of Tu et al. [28] who observed that the decomposition of cyanide in mine wastewater added with $\mathrm{H}_{2} \mathrm{O}_{2}$ increased as the alkalinity of the solution increased.

Figure 2 shows that the effect of removing cyanide by $\mathrm{H}_{2} \mathrm{O}_{2}$ in solution is different from tailing under the same conditions. The reason for this phenomenon may be that the cyanide in the solution, which is free cyanide, is easy to be treated, while the diffusion rate of cyanide in the tailings to the solution is lower than the removal rate by $\mathrm{H}_{2} \mathrm{O}_{2}$ of the solution.

3.3. Effect of $\mathrm{H}_{2} \mathrm{O}_{2}$ Concentration on the Decomposition of Cyanide. The ability of the decomposition of cyanide will be affected by the concentration of $\mathrm{H}_{2} \mathrm{O}_{2}$. Figure 3 shows the effect of $\mathrm{H}_{2} \mathrm{O}_{2}$ concentrations ranging from 1 to $4 \mathrm{~mL} / \mathrm{L}$ on the decomposition of cyanide. It is evident that an increase in $\mathrm{H}_{2} \mathrm{O}_{2}$ concentration increased the extent of decomposition in tailings; the most cyanide is leached from the tailings when $2 \mathrm{~mL} / \mathrm{L} \mathrm{H}_{2} \mathrm{O}_{2}$ is added to the solution.

In order to remove cyanide in tailings as much as possible, excessive $\mathrm{Na}_{2} \mathrm{~S}_{2} \mathrm{O}_{5}$ was added to the pretreatment, and the reaction occurs when $\mathrm{H}_{2} \mathrm{O}_{2}$ reached a certain concentration, resulting in the low efficiency of cyanide treatment at $2 \mathrm{~mL} / \mathrm{L}$ :

$$
\begin{aligned}
\mathrm{Na}_{2} \mathrm{~S}_{2} \mathrm{O}_{2}+5 \mathrm{H}_{2} \mathrm{O}_{2} & \longrightarrow \mathrm{Na}_{2} \mathrm{SO}_{4}+\mathrm{H}_{2} \mathrm{SO}_{4} \\
\mathrm{H}_{2} \mathrm{SO}_{4}+\mathrm{Na}_{2} \mathrm{SO}_{3} & \longrightarrow \mathrm{Na}_{2} \mathrm{SO}_{4}+\mathrm{S}+\mathrm{SO}_{2}+\mathrm{H}_{2} \mathrm{O} \\
\mathrm{SO}_{2}+\mathrm{H}_{2} \mathrm{O}_{2} & \longrightarrow \mathrm{H}_{2} \mathrm{SO}_{4}
\end{aligned}
$$

3.4. Effect of Contact Time on the Decomposition of Cyanide. Contact time is also the influence factor of $\mathrm{H}_{2} \mathrm{O}_{2}$ for the decomposition of cyanide [28]. Figure 4 shows the effect of contact time ranging from 1 to $8 \mathrm{~h}$ on the rate of decomposition of cyanide of lixiviant in tailings. The figure showed that cyanide decreased in the first $4 \mathrm{~h}$ and the content of cyanide increased after $4 \mathrm{~h}$. In the first four hours, $\mathrm{H}_{2} \mathrm{O}_{2}$ reacted with cyanide in the tailings, which caused the cyanide content in the solution to decrease, while most of the cyanides adsorbed on pyrite [28, 29] and chalcopyrite [30], which is widely distributed in gold ore, are driven by chemisorption of carbon. The remaining $\mathrm{H}_{2} \mathrm{O}_{2}$ could not continuously reduce the cyanide content in the tailings, and it might be that the 

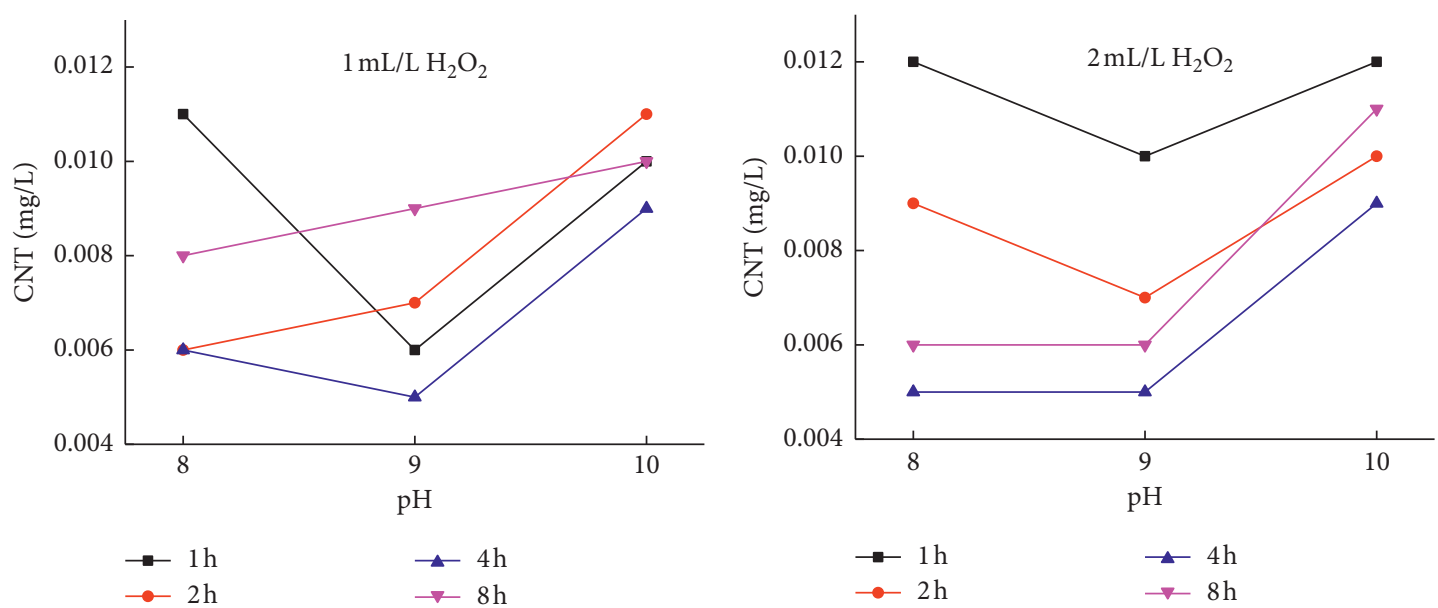

(a)

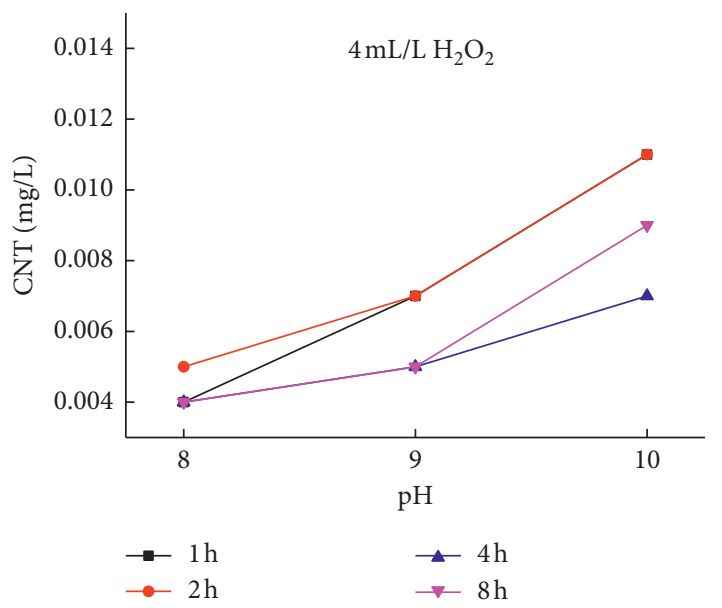

(b)

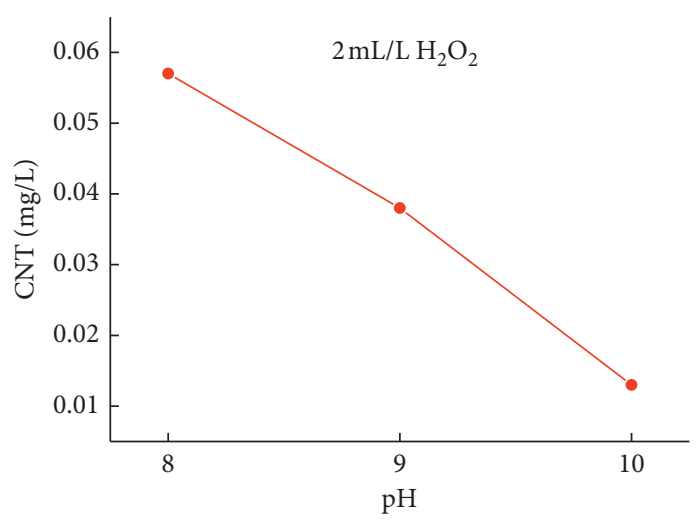

(c)

(d)

Figure 2: CNT as a function of $\mathrm{pH}$ in the presence of $\mathrm{H}_{2} \mathrm{O}_{2}$.

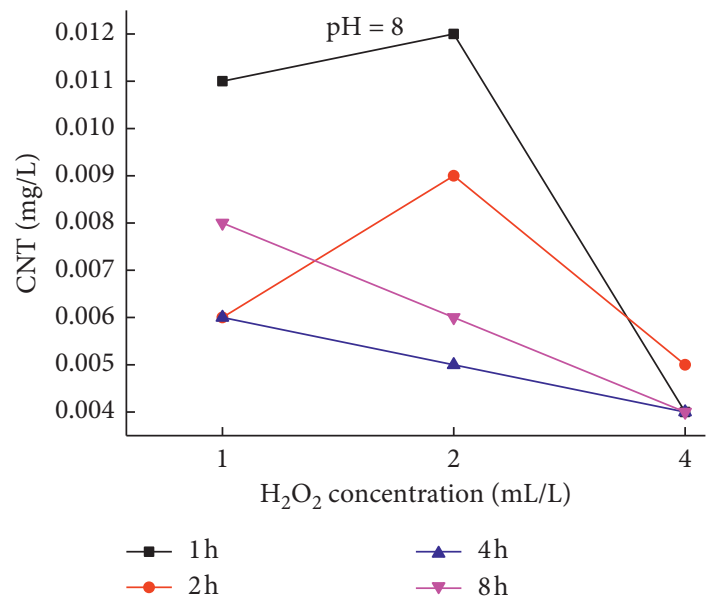

(a)

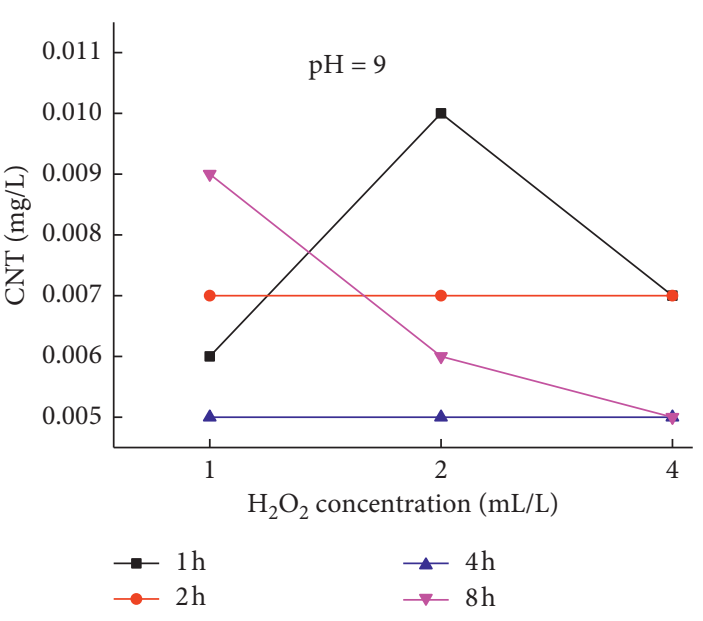

(b)

Figure 3: Continued. 


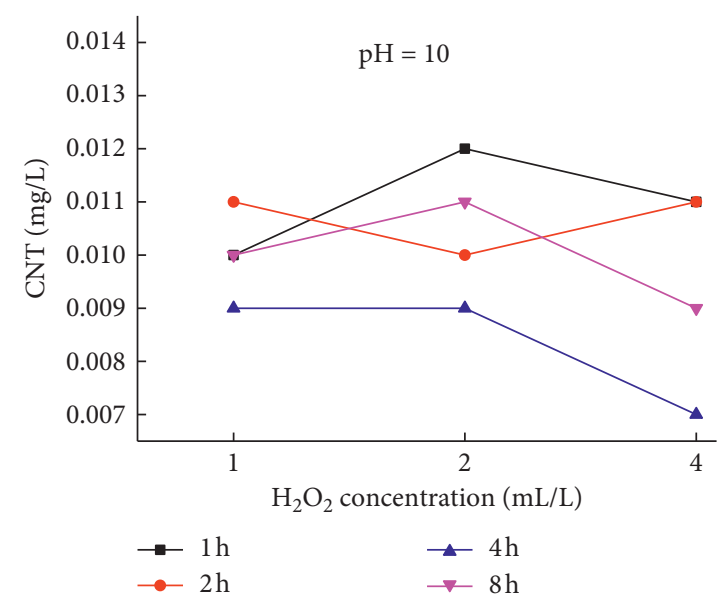

(c)

Figure 3: Cyanide as a function of $\mathrm{H}_{2} \mathrm{O}_{2}$ concentration.

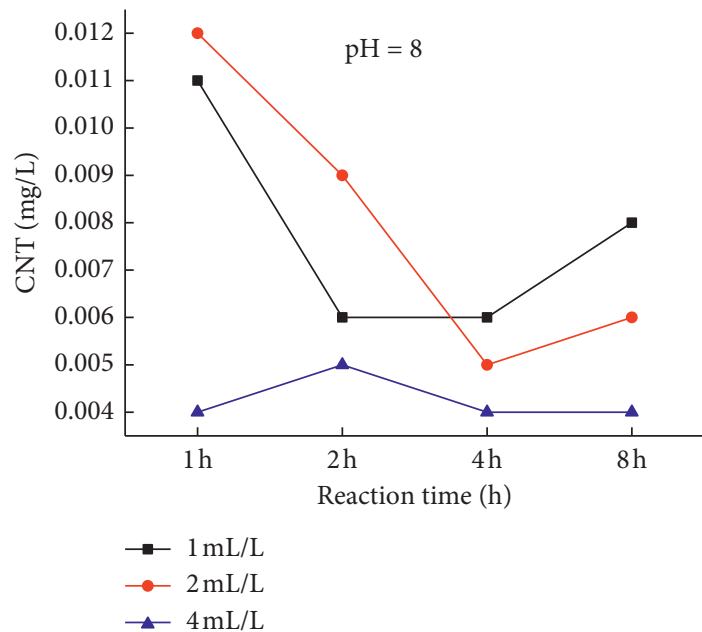

(a)

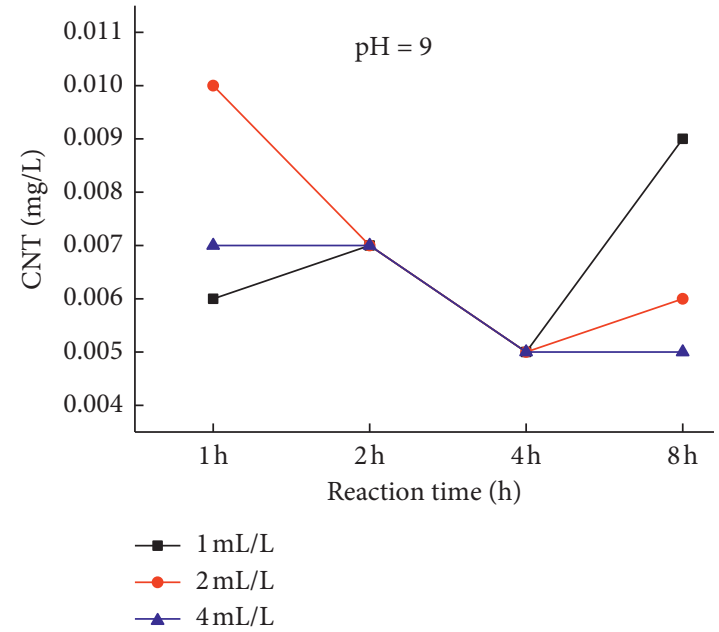

(b)

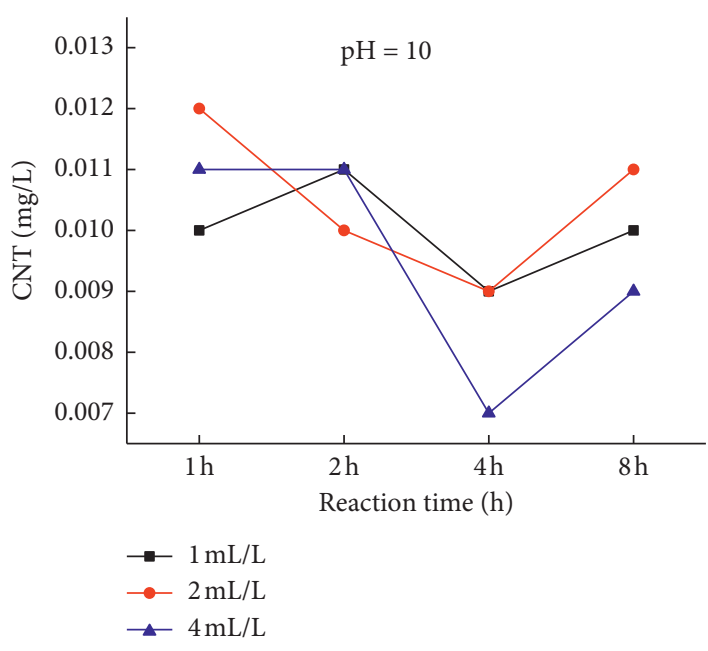

(c)

FIgURe 4: Cyanide as a function of contact time.

unreacted cyanide in the tailings adsorbed by activated carbon reentered the tailings with the concentration of $\mathrm{H}_{2} \mathrm{O}_{2}$ decreased. It is possible that the cyanide adsorbed by pyrite and activated carbon is gradually converted into free cyanide, and the unreacted cyanide in pulp re-enters the tailings with the decrease of $\mathrm{H}_{2} \mathrm{O}_{2}$ concentration. 
As explained above, the best conditions for decomposition of cyanide from leach tailings are first treated in $0.5 \mathrm{~g} / \mathrm{L}$ $\mathrm{Na}_{2} \mathrm{~S}_{2} \mathrm{O}_{5}$ at $\mathrm{pH} 10$ for 3 hours and then $2 \mathrm{~mL} / \mathrm{L} \mathrm{H}_{2} \mathrm{O}_{2}$ is added to the tailings at $\mathrm{pH} 9$ for 4 hours.

\section{Conclusions}

The decomposition of cyanide increased as the alkalinity of the solution and tailings increased in the presence of $0.5 \mathrm{~g} / \mathrm{L}$ $\mathrm{Na}_{2} \mathrm{~S}_{2} \mathrm{O}_{5}$. An increase in $\mathrm{pH}$ increased the extent of decomposition in solution in the presence of $\mathrm{H}_{2} \mathrm{O}_{2}$, while the effect on removing cyanide was best when $\mathrm{pH}$ was 9 in lixiviant of tailings. An increase in $\mathrm{H}_{2} \mathrm{O}_{2}$ concentration increased the extent of decomposition in solution. The cyanide decreased in the first $4 \mathrm{~h}$, and the content of cyanide increased after $4 \mathrm{~h}$ by the adsorption effect of active carbon and pyrite.

All the leaching metal of gold leaching tailings treated by $\mathrm{Na}_{2} \mathrm{~S}_{2} \mathrm{O}_{5}$ and $\mathrm{H}_{2} \mathrm{O}_{2}$ can meet the backfilling requirements $(0.05 \mathrm{mg} / \mathrm{L})$ of TSPC. Considering fully with effectiveness and practicability, the best conditions for decomposition of cyanide from leach tailings are first treated in $0.5 \mathrm{~g} / \mathrm{L}$ $\mathrm{Na}_{2} \mathrm{~S}_{2} \mathrm{O}_{5}$ at $\mathrm{pH} 10$ for 3 hours and then $2 \mathrm{~mL} / \mathrm{L} \mathrm{H}_{2} \mathrm{O}_{2}$ is added to the tailings at $\mathrm{pH} 9$ for 4 hours.

\section{Data Availability}

The data used to support the findings of the study are available from the corresponding author upon request.

\section{Additional Points}

Highlights. (i) Sodium and hydrogen peroxide for cyanide decomposition are applied. (ii) The factors affecting cyanide removal were explored. (iii) The optimal conditions for cyanide removal were examined. (iv) The lessons are useful for backfilling by gold tailings to develop efficient circularity.

\section{Conflicts of Interest}

The authors declared no potential conflicts of interest with respect to the research, authorship, and/or publication of this article.

\section{Acknowledgments}

This work was supported by the National Natural Science Foundation of China (no. 51904225), Science and Technology Program of Shaanxi (nos. 2020JQ-748 and 2019JM409), and Doctoral Start-up Program of Xi'an University of Science and Technology (nos. 2016QDJ031 and 201610).

\section{References}

[1] M. Botz, Cyanide Treatment Methods, in Mining Environmental Management, Mining Journal Books, London, UK, 2001.

[2] D. Adams, Gold Ore Processing: Project Development and Operations, Elsevier Science \& Technology, New York, NY, USA, 2016.
[3] L. Mekuto, Y. M. Kim, S. O. Ntwampe et al., "Heterotrophic nitrification-aerobic denitrification potential of cyanide and thiocyanate degrading microbial communities under cyanogenic conditions," Environmental Engineering Research, vol. 24, pp. 254-262, 2019.

[4] SWA (Safe Work Australia), Guide for Preventing and Responding to Cyanide Poisoning in the Workplace, Commonwealth of Australia, Sydney, Australia, 2013.

[5] S. Ebbs, "Biological degradation of cyanide compounds," Current Opinion in Biotechnology, vol. 15, no. 3, pp. 231-236, 2004.

[6] N. Kuyucak and A. Akcil, "Cyanide and removal options from effluents in gold mining and metallurgical processes," Minerals Engineering, vol. 50-51, pp. 13-29, 2013.

[7] E. Jaszczak, Z. Polkowska, S. Narkowicz, and J. Namieśnik, "Cyanides in the environment analysis problems and challenges," Environmental Science and Polluion Research, vol. 24, pp. 15929-15948, 2017.

[8] L. C. Razanamahandry, C. T. Onwordi, W. Saban et al., "Performance of various cyanide degrading bacteria on the biodegradation of free cyanide in water," Journal of Hazardous Materials, vol. 380, 6 pages, 2019.

[9] G. Asgari, A. Mohammadi, A. Poormohammadi, and M. Ahmadian, "Removal of cyanide from aqueous solution by adsorption onto bone charcoal," Fresenius Environmental Bulletin, vol. 23, no. 3, pp. 720-727, 2014.

[10] E. Yilmaz, F. Ahlatci, E. Y. Yazici, O. Celep, and H. Deveci, "Recovery of cyanide from effluents using carbon dioxide," Mugla Journal of Science and Technology, vol. 3, no. 2, pp. 171-177, 2017.

[11] E. Yilmaz, E. Y. Yazici, O. Celep, and H. Deveci, "Recovery of cyanide from effluents: SART process," Gumushane University Journal of Science and Technology Institute, vol. 9, no. 3, pp. 600-615, 2019.

[12] E. Yilmaz, E. Y. Yazici, O. Celep, and H. Deveci, "Processes for cyanide recovery from leach effluents," Scientific Mining Journal, vol. 58, no. 1, pp. 53-71, 2019.

[13] P. Breuer, C. Sutcliffe, and R. Meakin, "Comparison of industrial cyanide destruction processes," in Proceedings of International Mineral Processing Congress (IMPC) 2010, pp. 1483-1493, Brisbane, Australia, September 2010.

[14] D. W. Wei, L. Y. Chai, R. Ichino, and O. Masazumi, "Gold leaching in an alkaline tiourea solution," Journal of the Electrochemical Society, vol. 146, no. 2, pp. 559-563, 1999.

[15] A. Jauto, S. Memon, A. Channa, and A. Khoja, "Efficient removal of cyanide from industrial effluent using acid treated modified surface activated carbon," Energy Sources, Part A: Recovery, Utilization, and Environmental Effects, vol. 41, pp. 2715-2724, 2019.

[16] N. Pueyo, N. Miguel, J. L. Ovelleiro, and M. P. Ormad, "Limitations of the removal of cyanide from coking wastewater by ozonation and by the hydrogen peroxide-ozone process," Water Science and Technology, vol. 74, no. 2, pp. 482-490, 2016.

[17] S. Qiu, Z. G. Chen, P. Z. Guo, and J. Z. Shen, "Engineering application of heap elution process to deal with cyanide pollution soil," Journal of Environmental Engineering Technology, vol. 8, no. 1, pp. 104-108, 2018.

[18] C. C. Qi and A. Fourie, "Cemented paste backfill for mineral tailings management: review and future perspectives," Minerals Engineering, vol. 144, pp. 1-21, 2019.

[19] G. Laitos, "Cyanide mining and the environment," Pace Environmental Law Review, vol. 30, pp. 869-949, 2013. 
[20] Q. B. Tran, M. Lohitnavy, and T. Phenrat, "Assessing potential hydrogen cyanide exposure from cyanide-contaminated mine tailing management practices in Thailand's gold mining," Journal of Environmental Management, vol. 249, pp. 1-10, 2019.

[21] M. Esparza, C. Cueva, S. Pauker, V. Jentzsch, and M. Bisesti, "Combined treatment using ozone for cyanide from wastwatewater: a comparison," Revista Internacional De Contaminacion Ambiental, vol. 35, no. 2, pp. 459-467, 2019.

[22] C. C. Lv, Applied Fundamental Research of Comprehensive Recovering Valuable Elements from Cyanidation Tailing, Chinese Academy of Sciences, Beijing, China, 2017, in Chinese.

[23] G. A. Llerena and I. R. López, "Cyanide degradation from mining effluent using two reagents: sodium metabisulphite and the metabisulphite mixture with hydrogen peroxide," Tecciencia, vol. 13, no. 25, pp. 1-9, 2018.

[24] S. H. Li, L. M. Zhu, L. L. Ding, X. Xiong, and K. Liu, "Metallogenic age of xiajiadian gold deposit in the zhashuishanyang ore concentration, qinling orogenic belt and its geological significance," Mineral Deposits, vol. 38, no. 6, pp. 1278-1296, 2019, in Chinese.

[25] M. Pandit, D. K. Tyagi, and J. C. Kapoor, "Oxidation of cyanide in aqueous solution by chemical and photochemical process," Journal of Hazardous Materials, vol. 116, no. 1-2, pp. 49-56, 2004.

[26] M. Zhou, S. Y. Huang, and X. Qu, "Research on treatment of wastewater containing high concentration of cyanide by hydrogen peroxide catalytic oxidation," Industrial Water \& Wastewater, vol. 44, no. 5, pp. 31-34, 2013, in Chinese.

[27] M. Matsumura and T. Kojima, "Elution and decomposition of cyanide in soil contaminated with various cyanocompounds," Journal of Hazardous Materials, vol. 97, no. 1-3, pp. 99-110, 2003.

[28] Y. B. Tu, P. W. Han, L. Q. Wei et al., "Removal of cyanide adsorbed on pyrite by $\mathrm{H} 2 \mathrm{O} 2$ oxidation under alkaline conditions," Journal of Environmental Sciences, vol. 78, pp. 287-292, 2019.

[29] C. Zhao, D. Huang, J. Chen, Y. Li, Y. Chen, and W. Li, "The interaction of cyanide with pyrite, marcasite and pyrrhotite," Minerals Enginering, vol. 95, pp. 131-137, 2016.

[30] A. D. Bas, E. Koc, E. Y. Yazici, and H. Deveci, "Treatment of copper-rich gold ore by cyanide leaching, ammonia pretreatment and ammoniacal cyanide leaching," Transactions of Nonferrous Metals Society of China, vol. 25, no. 2, pp. 597-607, 2015. 